\title{
Research on the Strategy of E-commerce Teaching Reform Based on Brain Cognition
}

\author{
Ronggang Zhang ${ }^{1}$ \\ Northwest University of Political \\ Science and Law
}

\author{
Xiaheng Zhang ${ }^{2}$ \\ Northwest University of Political \\ Science and Law
}

\begin{abstract}
The rapid development of brain science and cognitive science and the demand of education and teaching reform urge the development of brain-based education movement. With e-commerce teaching reform strategy as the research target, and literature analysis method, case teaching method and questionnaire as research methods, this paper constructs the teaching design pattern based on brain cognition of the course of Introduction to ECommerce on the basis of the detailed analysis of teaching principle based on brain, teaching theory related to brain and theories related to teaching design, taking the course of Introduction to E-Commerce in colleges and universities as an example. The investigation and analysis of the course implementation and teaching effect verify that the teaching design pattern of e-commerce course based on brain cognition can promote students' interest in learning and knowledge mastery, providing a new teaching mode to be referred for e-commerce teaching reform.
\end{abstract}

\section{Keywords}

Brain Science $\bullet$ E-commerce Teaching $\bullet$ Teaching Elements $\bullet$ Teaching Design

\footnotetext{
${ }^{1}$ Correspondence to: Ronggang Zhang $(\mathrm{PhD})$, Business School, Northwest University of Political Science and Law, Xi’an710122, China. Email: zrg1168@126.com

${ }^{2}$ Business School, Northwest University of Political Science and Law, Xi'an710122, China. Email: zhangxiaheng@163.com
} 
The rapid development of brain science and cognitive science and the demand of education and teaching reform urge the development of brain-based education movement and make the scientific education gradually to become the focus of attention. The brain-cognition-based education movements originated in the United States in the 1990s (Hardiman, Rinne, Gregory \& Yarmolinskaya, 2012), followed by a large number of brainbased educational research results published in newspapers, media, and magazines. Brain-based education incorporates psychology and multiple educational paradigms, wherein the brain-related teaching theory (Peterson, 1984) advocates that teaching shall be based on the natural laws of the brain in light with constructivist education theory, and creates a rich and realistic learning environment in the student-cantered teaching design (Butterworth, Varma \& Laurillard, 2011). Since the 21st century, the research on brain-based education has become the focus of international organizations and countries. China has also actively devoted itself to the research on brain science and education, striving for a new breakthrough in this field.

Under the background of economic globalization, e-commerce witnesses a new era of vigorous development, which has penetrated into various industries at a rapid rate. As society's demand for interdisciplinary talents with e-commerce capabilities continues to increase, e-commerce course has become one of the required courses for many colleges and universities. Classroom teaching is the main channel of school education, thus it is an important factor to improve students' enthusiasm for learning and teaching quality as whether the teacher can design the teaching link that meets the students' cognitive rules according to the actual situation of the students (Ansari, 2012). Therefore, research on teaching design for e-commerce courses has important practical significance.

To sum up, based on the review of domestic and international literature on brain sciences and education, teaching design, and education and teaching reform and a detailed analysis of the brain's five natural learning systems, Caines' three-element teaching theory, and related theories of teaching design (Lyndbalta, 2006), this paper finally selects research on the strategy of e-commerce teaching reform based on brain cognition as research topic, constructs the teaching design pattern based on brain cognition of the course of Introduction to E-Commerce, taking the course of Introduction to E-Commerce in colleges and universities as an example, and designs each teaching link in detail. The investigation and analysis of the course implementation and teaching effect verify that the teaching design pattern of e-commerce course based on brain cognition can promote students' interest in learning and knowledge mastery, providing a new teaching mode to be referred for education and teaching reform.

\section{Related theoretical basis}

\section{Natural learning systems of the brain}

In the brain, the focus of neurons forms a "module", the connection of neurons between "modules" forma a "loop", and the connections between neurons form a "networks". The brain's learning system can be seen as a neural pathway formed by the interconnection of different modules. The schematic diagram of a neuronal pathway is shown in Figure 1 (Cardoza, 2011). Different loops handle different learning information, and educators influence learners to form specific reflection patterns by inputting relevant information to learners 
(Susser \& Ariga, 2006). Table 1 shows the five natural learning systems proposed by Given (Oxley \& Yeung, 2001), who points out that the course shall be designed to be lively, interesting and relevant to the actual situation of the students. The systems provide relevant reference basis for teachers' education and teaching.

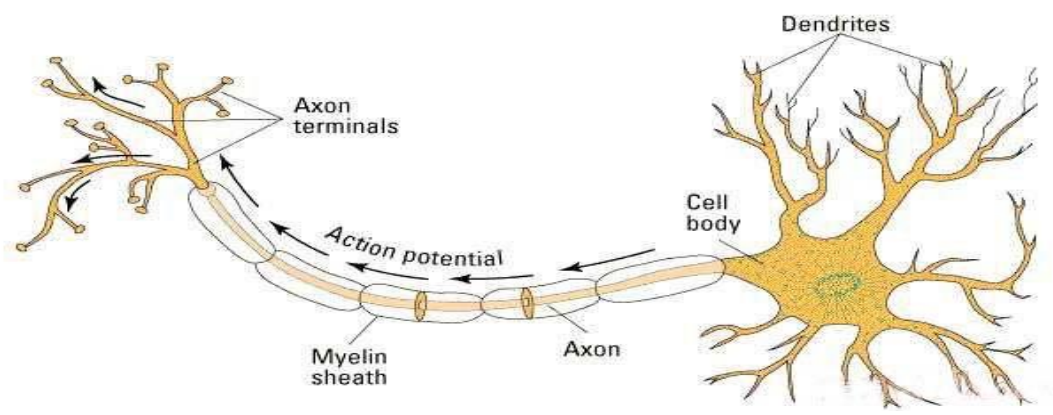

Figure 1. Neuronal pathways.

Table 1

Kevin's Natural Learning System

\begin{tabular}{|c|c|c|c|}
\hline $\begin{array}{l}\text { Brain Natural } \\
\text { Learning System }\end{array}$ & $\begin{array}{l}\text { The core } \\
\text { element }\end{array}$ & The role of teachers & Student needs \\
\hline Emotional learning & Passion & Mentor and Model & $\begin{array}{l}\text { Personal advantage is } \\
\text { respected }\end{array}$ \\
\hline Social learning & Cooperation & Collaborators & A sense of belonging \\
\hline Cognitive learning & Purpose & Promoters & Seek knowledge \\
\hline Physical learning & Action & Coach & which performed \\
\hline Reflective learning & Reflection & $\begin{array}{l}\text { Talent explorers and } \\
\text { leaders }\end{array}$ & $\begin{array}{l}\text { Self-monitoring and } \\
\text { growth }\end{array}$ \\
\hline
\end{tabular}

\section{Brain-related teaching principles}

The basic guideline to be followed in teaching is referred to as teaching principles in educational circles (Foster \& Lin, 2003). Brain-based education researchers such as the Caines, Rita Smilk-stein, and Jason have proposed brain-based teaching principles different from the past ones. This article mainly studies the Caines' teaching principles which have great influence on the educational practice. The Caines point out that the brainbased teaching design includes the following three elements (Vargas, Jóhannesdóttir, Sigurgeirsson, Thorsteinsson \& Karlsson, 2011):

Orchestrated immersion. The appropriate brain-based education requires teachers to complete the course content by means of establishing the topics of the course and the real project, and to provide the students with many kinds of sensory representations through storytelling, metaphor and other methods, (Glisky, 1992) so that the teaching content can be separated from the books and the blackboard to be vividly reflected in the students' minds. Therefore, the orchestrated immersion focuses on the way in which students obtain teaching content.

Relaxed alertness. Relaxed alertness is a mental state that is compatible with the brain's preference for challenge and search for meaning (Lewis, Baker \& Helding, 2015). Teachers shall work hard to create a learning atmosphere that incorporates small threats and major challenges, while adopting multiple supportive 
evaluations, with a purpose to achieve good communication and reflective practice in a cooperative and supportive atmosphere.

Active processing. Active processing is the only way for students to process information through reflection, meditation, and creative elaboration so as to give meaning to experience (Hora \& Holden, 2013). Teachers can develop students' active processing of learning content by means of video, computer, and role-playing.

\section{Teaching design of Introduction to E-Commerce Course based on brain cognition and its implementation}

\section{Brief introduction to the theory of teaching design}

At present, the teaching patterns widely used in schools includes two kinds of teaching design: "teachingoriented" teaching design and "learning-oriented" teaching design (Gess-Newsome, Southerland, Johnston \& Woodbury, 2003). Table 2 shows the comparison of the two kinds of teaching designs. Through comparison and analysis, it is found that each has its own advantages and disadvantages. The traditional "teaching-oriented" teaching design pays attention to the process of teaching by teachers and gives priority to knowledge teaching, but neglects the dominant role of students. The "learning-oriented" teaching design focuses on the students' "learning", emphasizing the learning process and training of students' abilities, but fails to give full play to the teachers' dominant role.

Table 2

A Comparison between "Teaching-base d" Instructional Design and "Learning-based" Instructional Design

\begin{tabular}{|c|c|c|}
\hline - & $\begin{array}{c}\text { To "teach" based instructional } \\
\text { design }\end{array}$ & $\begin{array}{l}\text { Teaching Design Based on } \\
\text { Learning }\end{array}$ \\
\hline Design positioning & Content and knowledge & Process and activities \\
\hline Design purpose & Impart knowledge & Develop skills \\
\hline Designing process & Systematic design & $\begin{array}{l}\text { Avoid procedural practices, } \\
\text { nonlinear }\end{array}$ \\
\hline $\begin{array}{l}\text { Teacher and student } \\
\text { positioning }\end{array}$ & The imparter of knowledge & Organizers and guides \\
\hline Learning evaluation & $\begin{array}{l}\text { Results-oriented, quantitative } \\
\text { evaluation }\end{array}$ & $\begin{array}{l}\text { Process-oriented, multiple } \\
\text { evaluation }\end{array}$ \\
\hline
\end{tabular}

\section{Teaching design of Introduction to E-Commerce course based on brain cognition and its implementation}

Through the comparison and analysis of traditional teaching patterns, this study puts forward a teaching design pattern based on brain cognition, taking "Introduction to E-Commerce" as an example, in accordance with the advantages of two teaching patterns.

Analysis of learning content. Based on the theory of brain cognition, this study re-integrates the content of the Introduction to E-Commerce and divides it into two parts: the concepts related to a certain theme, and wellstructured knowledge of the principles and the non-well-structured knowledge with the application of well- 
structured knowledge to the context of specific problems. Figure 2 shows the content of three modules in the integrated Introduction to Electronic Commerce course (Simkins, 2000).

Figure 3 illustrates the classification of knowledge points and categories involved in learning by taking "Ecommerce logistics system" as an example. The content of this section contains a large amount of wellstructured and non-well-structured knowledge and students need to apply the knowledge they have learned to specific situations. Therefore, different teaching methods should be used for different knowledge in teaching design. For example, most of the well-structured knowledge can be taught to students mainly through lecturing, so that students can understand it through meaningful abstraction and analysis. However, the non-wellconstructed knowledge has complex content and is difficult to understand, thus teachers can help students to learn it by creating relevant situations and using multimedia and other teaching equipment.

Teaching design of Introduction to E-Commerce course based on brain cognition and its Implementation. (1).Selection of teaching methods. In the brain-cognition-based teaching activities, appropriate teaching methods can allow students to immerse themselves in the activities and present the teaching content vividly in the students' brains. According to the cognitive law of the brain, the teaching methods adopted in this study mainly include the following three kinds (Hora et al., 2013): 1) Lecturing. Different from the traditional lecturing, the lecturing here refers to the teaching methods in which teachers use multimedia to present knowledge points to the students through pictures, sounds, or videos, in accordance with the teachers' explanation so as to facilitate students' understanding. 2) Group discussion. For boring knowledge points, teachers can divide the students into study groups with 3-5 persons for discussion and learning. After summarizing the knowledge points, the representative of each group makes a report about their group learning results and the teachers shall give their comments accordingly. 3) Case analysis. The case analysis method can provide students with a large number of practical problems in the industry. Teachers and students can try to find solutions to those problems in the cases through collective discussion and analysis, so that students can apply the knowledge in the textbooks to practical problems, improving their comprehensive analyzing abilities. 4) Practice or simulated practice. Through the Internet or simulation experiment platform, students can complete relevant operations by themselves, which can stimulate students' interest in learning, make them to feel the joy of success, and deepen their absorption of knowledge. 5) Situation creation. By creating problem situation, collaborative situation, and story situation, students can be introduced into real learning situations to narrow the gap between knowledge and problem solving.

(2) Teaching evaluation design. A variety of supportive evaluations can help teachers to know students' understanding of knowledge and problems, allowing teachers to communicate with students about their learning in a timely manner and allowing students to carry out reflective practice, thus to improve teaching effects. The evaluation methods used in this study include the following: 1) Diagnostic evaluation. The diagnostic evaluation is carried out in the preparation stage of teaching, wherein the preparation of students before class and the current knowledge and skills of students are assessed through their homework before class. For the diagnostic evaluation, teachers can design the course with specific targets and adopt appropriate teaching methods. 2) Formative evaluation. Questions and practices in the teaching process, and test and assignment after class are used to feedback students' learning status, thus teachers can take timely improvement measures and adjust 
teaching content in accordance with students' classroom performance and test scores, so as to achieve their teaching objectives.

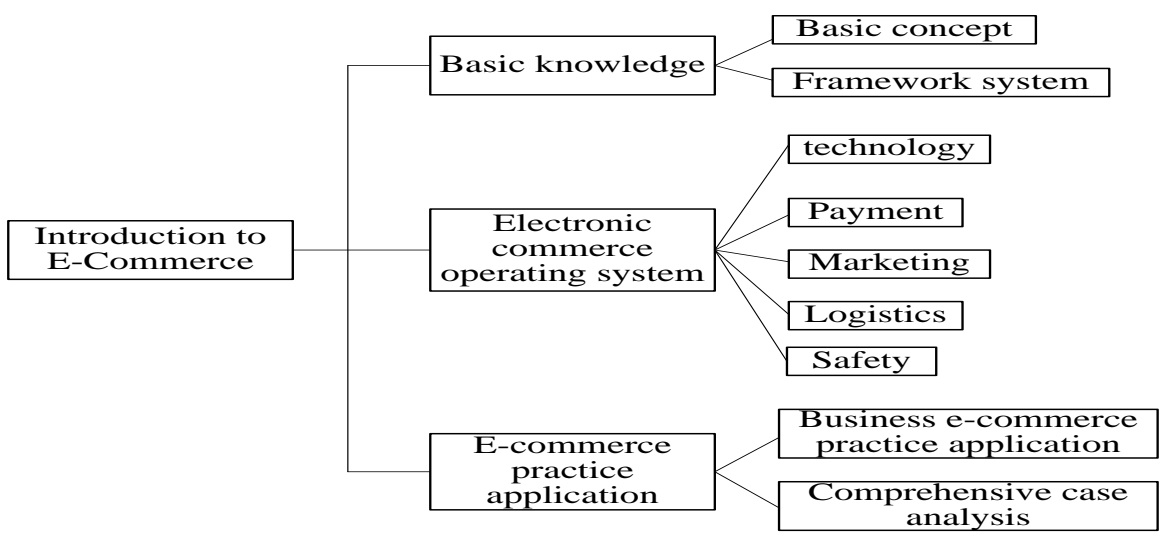

Figure 2. Teaching Content of Introduction to E-Commerce.

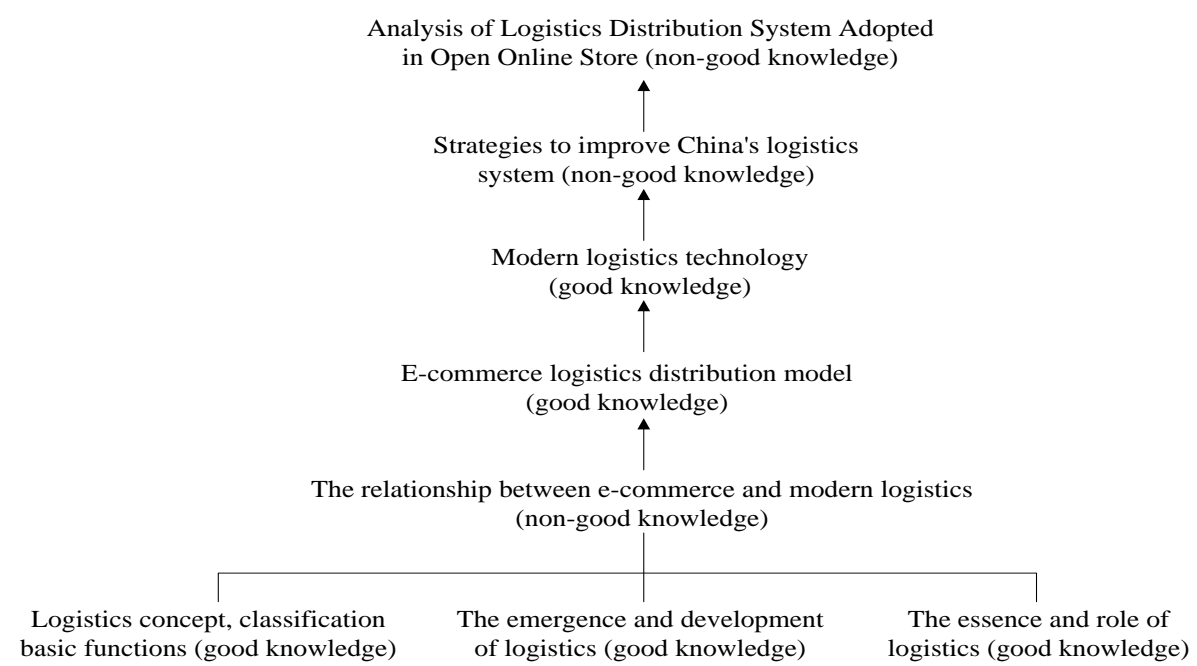

Figure 3. Structural relationship between knowledge points and categories of e-commerce logistics system.

(3) Teaching design of Introduction to E-Commerce course based on brain cognition. Figure 4 shows the flow chart of the teaching design of the Introduction to E-Commerce course based on brain cognition. The process is divided into three stages: before class, during class and after class. Before class, the teachers assign the prepared teaching tasks to the students, and the students complete the corresponding tasks through selfstudy and find out their problems in learning. Teachers conduct diagnostic evaluation based on students' feedback and further adjust their teaching plans. During the class, teachers create a good learning atmosphere for the students and adopt one of the teaching methods proposed in this paper according to the specific course content. The students complete the learning task assigned by the teacher through group discussion and problem solving, and then consult on difficult problems. After class, students complete the homework assigned by their 
teachers, and consolidate and absorb the knowledge through the network and the learning resource platform provided by their teachers. Teachers adjust their teaching plans and teaching content according to the feedback of the students in a timely manner.

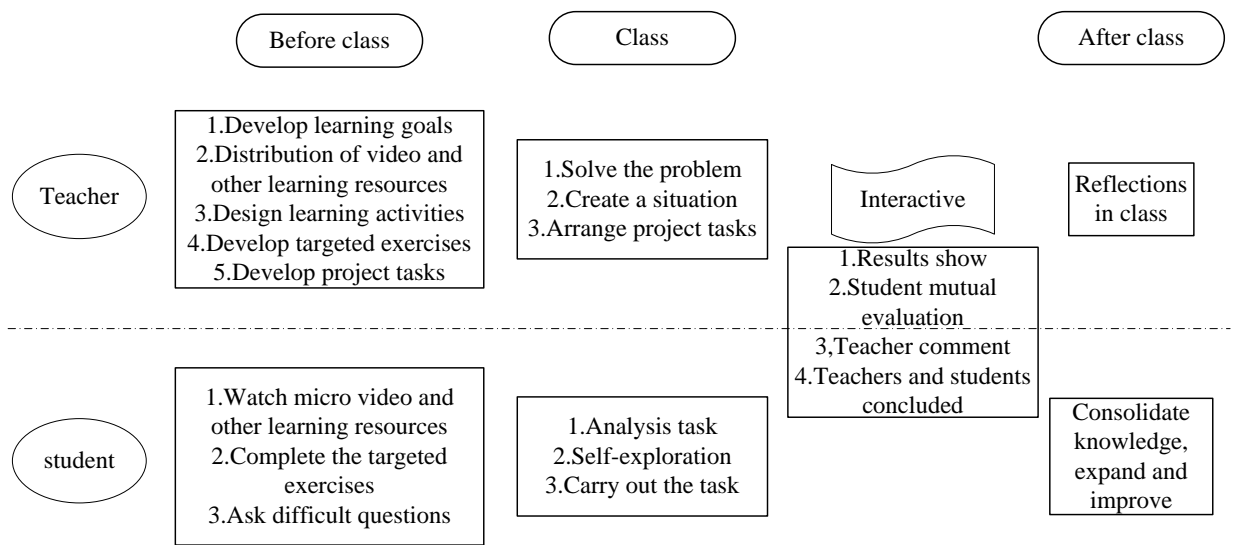

Figure 4. Course teaching design flow chart.

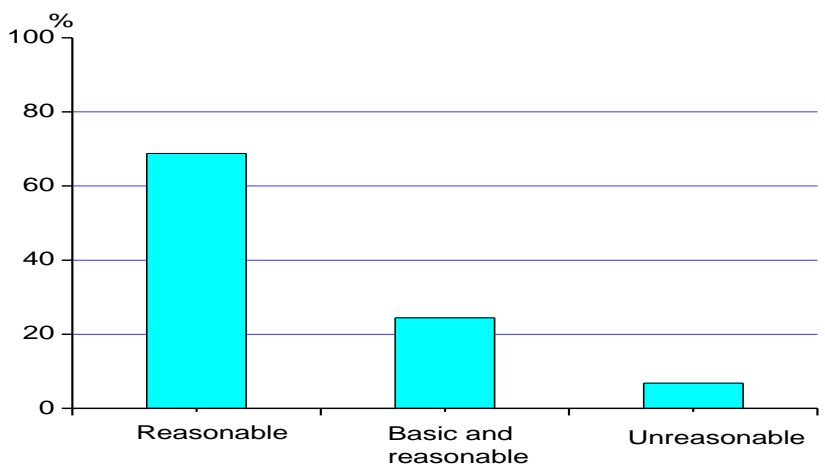

Figure 5. The breadth and depth of teaching content.

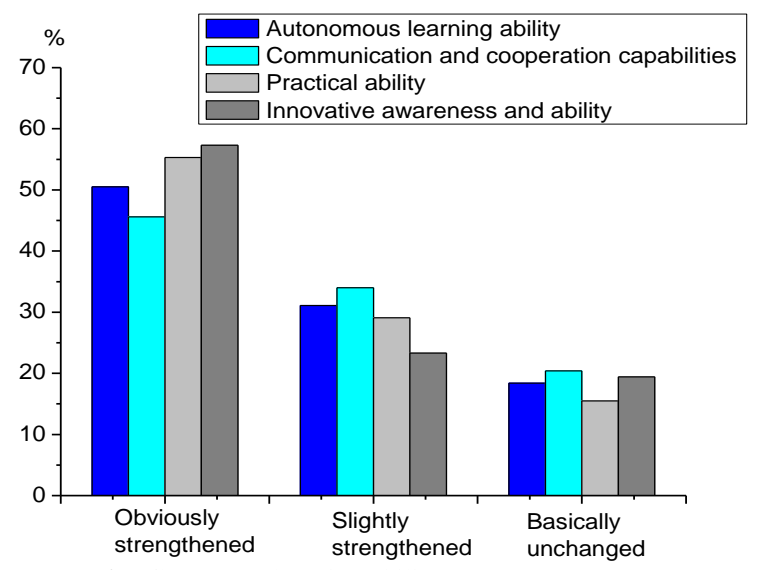

Figure 6. Influence on learning ability. 
(4) Analysis of teaching effect of Introduction to E-Commerce course based on brain cognition. With a total of 98 students from the e-commerce Classes 1 and 2 of Beijing Business School selected as subjects, this research studies the course teaching design pattern of the Introduction to E-Commerce course based on the brain cognition in the aspects of the teaching content, the teachers' teaching methods and teaching effects of the course. 1) Teaching content. Figure 5 shows the results of the survey on the rationality of the course content design of the Introduction to E-Commerce. According to the Figure, nearly $70 \%$ of the students think the course content design is reasonable, and only $6.8 \%$ of the students consider unreasonable, indicating that the teaching content is in line with the students' cognitive laws and most students can accept it. 2) Teachers' teaching methods According to the questionnaire on students' preference for teachers' teaching methods shown in Table 3, most of the students accept the traditional classroom teaching method, and $71.1 \%$ of the students like experiments under the guidance of their teachers. Their affection for other teaching methods slightly decreases, but they also show a relatively strong interest. It shows that the traditional teaching pattern is deeply rooted in the students' mind. In the future classroom teaching, teachers shall gradually reduce the proportion of their lecturing and enrich their classroom teaching methods according to the cognition laws of students' brain. 3) Classroom teaching effects. Figure 6 shows the results of survey on the impact of the Introduction to E-Commerce course on student ability and Figure 7 shows the results of the course satisfaction survey. According to these figures, more than $50 \%$ of students think that their autonomous learning ability, innovation awareness and ability, and communication and cooperation capabilities have been improved through the study of the course, about $30 \%$ of students believe that their abilities are slightly enhanced and more than $75 \%$ of students expressed satisfaction or general satisfaction with the course.

Table 3

Student's Preference for Teachers to Use Teaching Methods

\begin{tabular}{lcccc}
\hline Teaching methods & Like very much & Prefer & General & Dislike \\
\hline Classroom teaching & $42.6 \%$ & $33.1 \%$ & $17.6 \%$ & $6.7 \%$ \\
Class discussion and answer questions & $20.5 \%$ & $27.9 \%$ & $35.1 \%$ & $16.4 \%$ \\
Student group discussion, keynote speech & $24.4 \%$ & $28.3 \%$ & $30 \%$ & $17.4 \%$ \\
Group Cooperative Learning & $20.5 \%$ & $266.3 \%$ & $29 \%$ & $24.2 \%$ \\
Instruct student design and research & $19.5 \%$ & $27.3 \%$ & $33.9 \%$ & $19.3 \%$ \\
Instruct students to experiment & $37 \%$ & $34.1 \%$ & $20.3 \%$ & $8.6 \%$ \\
\hline
\end{tabular}

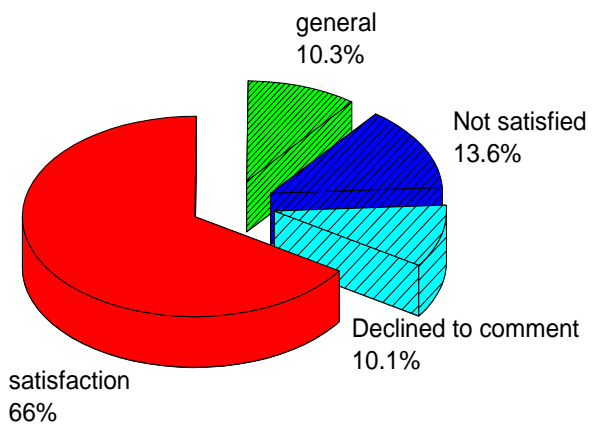

Figure 7. Course satisfaction survey. 
Through the analysis of the above data, it can be seen that most students accept the teaching design of the Introduction to E-Commerce course based on brain cognition and believe that their knowledge and abilities have been improved.

\section{Conclusion}

With e-commerce teaching reform strategy as the research target and with references to the literature both home and abroad, this paper constructs the teaching design pattern of the course of Introduction to E-Commerce based on brain cognition. The conclusions are drawn as follows.

(1) Based on the analysis of natural learning system of the brain and brain-related theories and comparative analysis of the traditional "teaching-oriented" wand "learning-oriented" teaching patterns, this paper constructs the teaching design pattern based on the brain cognition.

(2) This paper carries out a detailed teaching design for the Introduction to E-Commerce course based on brain cognition, and proposes the corresponding teaching methods and evaluation methods.

(3) The investigation and analysis of the implementation of the Introduction to E-Commerce course based on brain cognition and teaching effect verify that the teaching design pattern of e-commerce course based on brai

\section{References}

Ansari, D. (2012). Culture and education: New frontiers in brain plasticity. Trends in Cognitive Sciences, 16(2), 93-95. http://dx.doi. org/10.1016/j.tics.2011.11.016\}

Butterworth, B., Varma, S., \& Laurillard, D. (2011). Dyscalculia: from brain to education. Science, 332(6033), 1049-1053. http://dx.doi. org/10.1126/science.1201536

Cardoza, M. P. (2011). Neuroscience and simulation: an evolving theory of brain-based education. Clinical Simulation in Nursing, 7(6), e205-e208.

Fischbein, N., Dillon, W. P., \& Barkovich, A. J. (2000). Teaching atlas of brain imaging. Journal of Magnetic Resonance Imaging, 15(10), 120-120.

Foster, J., \& Lin, A. (2003). Individual differences in learning entrepreneurship and their implications for webbased instruction in e-business and e-commerce. British journal of Educational Technology, 34(4), 455-65.

Gess-Newsome, J., Southerland, S. A., Johnston, A., \& Woodbury, S. (2003). Educational reform, personal practical theories, and dissatisfaction: The anatomy of change in college science teaching. American Educational Research Journal, 40(3), 731-767. http://dx.doi. org/10.3102/00028312040003731

Glisky, E. L. (1992). Computer-assisted instruction for patients with traumatic brain injury: Teaching of domain-specific knowledge. Journal of Head Trauma Rehabilitation, 7(3), 1-12.

Hardiman, M., Rinne, L., Gregory, E., \&Yarmolinskaya, J. (2012). Neuroethics, neuroeducation, and classroom teaching: where the brain sciences meet pedagogy. Neuroethics, 5(2), 135-143. 
Hora, M. T., \& Holden, J. (2013). Exploring the role of instructional technology in course planning and classroom teaching: Implications for pedagogical reform. Journal of Computing in Higher Education, 25(2), 68-92. http://dx.doi. org/10.1007/s12528-013-9068-4

Lewis, E. B., Baker, D. R., \& Helding, B. A. (2015). Science teaching reform through professional development: teachers' use of a scientific classroom discourse community model. Science Education, 99(5), 896-931.

Lyndbalta, E. (2006). Using literature and innovative assessments to ignite interest and cultivate critical thinking skills in an undergraduate neuroscience course. CBE - Life Sciences Education, 5(2), 167-174.

Oxley, J. E., \& Yeung, B. (2001). E-commerce readiness: Institutional environment and international competitiveness. Journal of International Business Studies, 32(4), 705-723.

Peterson, R. W. (1984). Great expectations: collaboration between the brain sciences and education. American biology teacher, 46(2), 74-80.

Simkins, T. (2000). Education reform and managerialism: comparing the experience of schools and colleges. Journal of Education Policy, 15(3), 317-332. http://dx.doi. org/ 10.1080/02680930050030455

Susser, B., \& Ariga, T. (2006). Teaching e-commerce web page evaluation and design: a pilot study using tourism destination sites. Computers \& education, 47(4), 399-413.

Vargas, R., Jóhannesdóttir, I. T., Sigurgeirsson, B., Thorsteinsson, H., \& Karlsson, K. A. (2011). The zebrafish brain in research and teaching: A simple in vivo and in vitro model for the study of spontaneous neural activity. Advances in Physiology Education, 35(2), 188-96. 